Cite as: Swirski, H., \& Baram-Tsabari, A. (2014). Bridging the gap between the science curriculum and students' questions: Comparing linear vs. hypermedia online learning environments. Interdisciplinary Journal of E-Learning and Learning Objects, 10, 153-175. Retrieved from http://www.ijello.org/Volume10/IJELLOv10p153-175Swirski0898.pdf

\title{
Bridging the Gap between the Science Curriculum and Students' Questions: Comparing Linear vs. Hypermedia Online Learning Environments
}

\author{
Hani Swirski and Ayelet Baram-Tsabari \\ Department of Education in Science and Technology \\ Technion - Israel Institute of Technology, Haifa, Israel
}

hanis@tx.technion.ac.il ayelet@technion.ac.il

\begin{abstract}
While interest is central to learning, considerable disparities have been reported between students' science interests and the science curriculum. This study explores how 5th grade students' $(n=72)$ competence, relatedness and interest levels changed as a consequence of using two online learning environments, which bridged the students' anonymous curiosity questions and the required science curriculum on the topic of "Natural Resources". One environment provided answers to the students' questions (a 'linear' environment), whereas the other provided relevant links and sent the students to find the answer by themselves (a 'hypermedia' environment). Each student experienced both of the environments, and their competence, relatedness and interest levels were examined using a closed pre/posttest questionnaire. Interest level increased only after experiencing learning with the linear environment, whereas competence level increased only after using the hypermedia environment. These findings point to the potential of using online learning environments to narrow the gap between the curriculum and students' interests, while emphasizing the pedagogical need for diverse online environments for different learners and learning goals.
\end{abstract}

Keywords: Interest, Motivation, Students' questions, Online learning environment, Hypermedia, Elementary school, Science curriculum, Science education.

\section{Introduction}

Material published as part of this publication, either on-line or in print, is copyrighted by the Informing Science Institute. Permission to make digital or paper copy of part or all of these works for personal or classroom use is granted without fee provided that the copies are not made or distributed for profit or commercial advantage AND that copies 1) bear this notice in full and 2) give the full citation on the first page. It is permissible to abstract these works so long as credit is given. To copy in all other cases or to republish or to post on a server or to redistribute to lists requires specific permission and payment of a fee. Contact Publisher@InformingScience.org to request redistribution permission.
The importance of student interest in learning has been widely acknowledged in the literature (Kaplan, Katz, \& Flume, 2012; Krapp \& Prenzel, 2011; Renninger \& Hidi, 2011). However, in many cases, students' questions, which may express their interests, do not receive an adequate response in class. Among the reasons are time constraints on teaching, teachers' lack of confidence about their own knowledge, incompatibility between the topic and the students' level

\section{Editor: Janice Whatley}

An earlier, shorter version of this paper was presented at the Chais conference 2014, in Raanana, Israel, and included in Y. Eshet-Alkalai, A. Caspi, N. Geri, Y. Kalman, V. Silber-Varod, \& Y. Yair (Eds.), Proceedings of the Chais Conference for the Study of Innovation and Learning Technologies 2014: Learning in the Technological Era. Raanana: The Open University of Israel. 
of understanding, or between the question and the requirements of the curriculum (Hagay \& Baram-Tsabari, 2011).

In Israel, where the current study took place, a disparity was found between the high school biology curriculum and students' interests, as reflected by their questions (Hagay \& Baram-Tsabari, 2011). In order to bridge this gap, Hagay and Baram-Tsabari (2011) suggested the implementation of a "shadow curriculum", a strategy for incorporating students' interest into the formal curriculum. The teacher asks students to anonymously write down questions they have about a certain topic. These questions are mapped to the most relevant milestones of the curriculum, and incorporated into teaching.

The study described below explored the effect of this "shadow curriculum" strategy on students' interest and intrinsic motivation in an elementary school setting, using two online learning environments that were developed based on students' questions. While differences in students' interest level using online learning environments have been studied (e.g. Barak, Ashkar, \& Dori, 2011), here the two environments differed in terms of their pedagogical strategy. One environment provided users with a straight answer to the student's question (a linear environment - LE), whereas in the other, users were guided and provided with resources to look for the answer themselves using hypertext links (a hypermedia environment - HE).

The literature has reported mixed results regarding the effectiveness of hypermedia-based learning environments (Dillon \& Gabbard, 1998; Scheiter \& Gerjets, 2007). On the one hand, the main advantage of hypermedia environments, compared to more traditional forms of learning environments, is that learners have control over the order in which they access different information units (Shapiro \& Niederhauser 2004), which may increase students' interest level (Scheiter \& Gerjets, 2007). On the other hand, these same features may lead to disorientation, distraction and cognitive overload (Rouet \& Levonen, 1996). Thus, comparing students' effective outcomes between the two types of environments may enrich our understanding of the advantages and disadvantages of each environment in the context of students' science interests and intrinsic motivation.

\section{Literature Review and Conceptual Framework}

\section{Interest in Science Learning}

"The word 'interest' suggests, etymologically, what is between, that which connects two things otherwise distant", according to Dewey (1916, p. 88), who saw interest as a crucial factor in learning. In fact, interest has a strong influence on students' cognitive functioning (Ainley, Hidi, \& Berndorff, 2002) and learning outcomes (Swarat, Ortony, \& Revelle, 2012). Within science education, students' interest levels have been found to explain and predict their career choice (e.g., Ainley \& Ainley, 2011; Cannady, Greenwald, \& Harris, 2014; Koul, Lerdpornkulrat, \& Chantara, 2011; Krapp \& Prenzel, 2011).

Despite its importance, over the past decade, it has been widely accepted that students' interest in learning science is declining in developed countries and science professions are less attractive to young people (Potvin \& Hasni, 2014). "Across OECD countries, close to $40 \%$ of high-school students who come top in science subjects have no interest in pursuing a science-related career" $(\mathrm{OECD}, 2009) \mathrm{A}$ critical time period is the transition from primary to secondary education, in which many students rapidly lose their interest in science (Christidou, 2011).

Addressing students' questions during science teaching has been shown to influence their intrinsic motivation (Hagay \& Baram-Tsabari, 2011). According to Deci and Ryan's (1985) SelfDetermination Theory, intrinsic motivation is based on three basic human psychological needs: (1) a need for competence, which refers to a sense of self-efficacy, (2) a need for relatedness, 
which refers to a sense of security and appreciation, and (3) a need for autonomy, which refers to the sense of freedom to act while driven by inner interests and not by extrinsic rewards.

\section{Students' Questions}

Students' questions have become a research topic in the last two decades, due to their potential to promote meaningful learning and scientific inquiry (Chin \& Osborne, 2008). The questioning process is important in integrating thinking and learning (Cuccio-Schirripa \& Steiner, 2000) and can promote higher-order thinking skills (Hu \& Chiou, 2012). Science students' questions can direct their learning and foster discussion. It may help them self-evaluate and monitor their understanding and increase their motivation and interest (Chin \& Osborne, 2008).

Scardamalia and Bereiter (1992) reported a correlation between students' knowledge level and their question types. In elementary school, students are likely to ask basic factual and explanatory questions. Baram-Tsabari and Yarden (2005) found that elementary school students tend to ask more general curiosity questions than other age groups. Thus, even asking questions themselves might be a building block in their learning skills, indicate interest in the content, and provide a useful resource for teaching and learning

Students' questions may also be used as indicators of students' interest (e.g., Baram-Tsabari \& Yarden, 2005; Chin \& Osborne, 2008; Hagay \& Baram-Tsabari, 2011; Jidesjö, Oscarsson, Karlsson, \& Strömdahl, 2009). When students raise questions, they express scientific concepts in their own words using their prior knowledge (Baram-Tsabari \& Yarden, 2007). One of the advantages of this approach over closed-ended questionnaires is students' ability to express their authentic interests, rather than respond to a pre-defined list suggested by a researcher. Therefore, students' questions are conceptualized in this study as an expression of students' voice.

\section{Students' Voice and the Elementary School Science Curriculum}

Over the last decades, there has been growing interest in giving students a voice in decision making about factors that influence their lives in school (Hennessy, 1999). Incorporating students' voice into decision making is viewed as a useful and pragmatic practice (Davie \& Galloway, 1996) and gives students a sense of ownership (Hennessy, 1999).

"The more educators give students choice and control...the more motivation and engagement are likely to rise" (Toshalis \& Nakkula, 2012). Students' engagement can contribute to the interpersonal dimension and integrating students' questions in class strengthens the connection between students and their teacher (Hagay \& Baram-Tsabari, 2012). "If curriculum relevance is to have any meaning, it cannot exclude the views of the students themselves" (Jenkins \& Nelson, 2005, p.53).

Although relevance is endorsed, in actual practice students' voices are often marginalized, especially with regard to the content of the curriculum (Murray \& Reiss, 2005). As Cook-Sather (2002, p.3) pointed out, "there is something fundamentally amiss about building and rebuilding an entire system without consulting at any point those it is ostensibly designed to serve." The students, for whom the curriculum was constructed, have no influence on its content.

The Israeli elementary school science curriculum is based on the Science, Technology, and Society (STS) approach (Israeli Ministry of Education, 2013), which combines several scientific fields, such as physics, biology and chemistry. The STS approach emphasizes the relevance of the science content to students' everyday life, and arguably therefore better responds to their interests. Therefore, this study was devised to explore the connection between the elementary students' voice and the science curriculum. 


\section{Online Learning Environments}

An Online Learning Environment (OLE) refers to learning occurring in a specific web-based area. The contribution of OLE has been studied extensively in terms of achievement (e.g., Dori, Barak, \& Adir, 2003; Hans, Kali, \& Yair, 2011), motivation (e.g., Barak et al., 2011; Rosen, 2009) and pedagogical aspects (Cohen, Kalimi, \& Nachmias, 2013; Geri, Gafni, \& Winer, 2014). OLE combines textual and visual information, which has been shown to contribute to better understanding (Hsu, Hwang, Chuang, \& Chang, 2012; Mayer \& Moreno, 2003) and increase students' interest level (Barak et al., 2011).

One of the essential components of OLE is the hypermedia technology that is implemented in many commonplace devices. Hypermedia technology can be seen as augmentation of hypertext by multimedia elements such as video, animation, and sounds (Rouet \& Levonen, 1996). According to Delany and Gilbert (1991, as cited in Dillon \& Gabbard, 1998) "hypermedia represents a natural form of representation with respect to the workings of the human mind."

In the context of learning, the advantage of hypermedia environments, compared to more traditional forms of learning environments, is learners' control over the order in which they access different information units (Shapiro \& Niederhauser 2004). The learner has "the freedom to decide when and which information to access" (Scheiter \& Gerjets, 2007, p. 289). Thus, on the one hand, it is perceived as effective for learning (Jonassen, 1986). However, on the other hand, too many options may be frustrating. Thus, "it is important to give learners limited rather than unlimited control" (Kirschner \& van Merriënboer, 2013, p. 178). Several studies have indicated that the hypermedia technology may be less effective than the use of simple linear text. Among the disadvantages are disorientation, distraction and cognitive overload for the learners (Falc, 2013; Rouet \& Levonen, 1996).

In the study described below, two OLEs, which differed in their pedagogical strategy, were explored. One environment provided students with answers to questions. This environment is referred to as the "linear environment" since the reading flow is linear, and the learner is "navigated' by the writer of the linear text. The second environment directed students to look for the answer using hypertext links. This environment is referred to as the "hypermedia environment" since it is consistent with Scheiter \& Gerjets's definition (2007, p. 287) that "hypermedia learning environments consist of network-like information structures, where fragments of information are stored in nodes that are interconnected and can be accessed by electronic hyperlinks".

In this study we explored the effectiveness of the two approaches to increase students' intrinsic motivation in science learning.

\section{Research Goal and Questions}

The main goal of this study was to explore the application of the "shadow curriculum" strategy for incorporating students' interest into the formal curriculum by using OLE. Specifically, we examined the effects of two types of OLEs on elementary students' interest and intrinsic motivation. Both environments were based on students' questions on the topic "natural resources". The research questions were:

1. To what extent are elementary school students' questions on the topic "natural resources" addressed by the science curriculum?

2. How does using a linear environment affect students' level of interest, compared to a hypermedia environment?

3. How does using a linear environment affect students' levels of perceived competence and relatedness, compared to a hypermedia environment? 


\section{Methodology}

\section{Participants}

This study involved 72 (37 males, 35 females) 5th grade students (10-11 years old) from three classes in a public elementary school in the northern part of Israel. The school is characterized by average academic achievement and attitudes to science similar to those found in public schools with the same socio-economic level (Israeli Ministry of Education \& RAMA, 2012). However, the students' appreciation of science classes was relatively low, compared to similar public schools: $55 \%$ of the 5 th grade students in this school reported enjoying science lessons, whereas the national mean is $67 \%$. Fifth grade students were chosen for this study due to their relatively high skills in phrasing questions compared to younger elementary students. The school was chosen for its accessibility, since the first author taught there at the time of data collection.

The research design is an extension of the "Pretest/posttest nonequivalent groups" (Campbell \& Stanley, 1963) involving two intervention groups, one comparison group (which did not take part in any intervention but learned the same topics) and three measurements.

The roles of the two intervention groups and the comparison group were randomly assigned to three classes. The same teacher taught all three science classes for four hours weekly. The classes were characterized by similar science achievement levels.

\section{Students' Questions: Collection}

A total of 161 questions addressing the topic of "natural resources" were anonymously collected from students in three 5 th grade classes.

The questions were written individually by the students at the beginning of the unit using the anonymous questionnaire (Appendix A) asking them to write questions that interested them about this topic. Thus, the questions were based only on prior knowledge and interest. The gender of the students was recorded on the sheet they handed in. Students were asked to explain why they found the questions to be interesting. Most of the students did not answer this part or wrote repetitive answers such as "curiosity"; thus, we do not report on this data.

\section{Students' Questions: Analysis}

The questions were analyzed for their alignment with the curriculum, based on a method developed by Hagay and Baram-Tsabari (2011). Questions were mapped to the milestones of the curriculum and classified as having a direct or an indirect answer in the curriculum. For example, the question "How do natural resources affect our lives?" has a direct answer in the curriculum in the section "Natural resources as suppliers of human needs" (Israeli Ministry of Education, 2013). In contrast, the question " How long can we survive without natural resources?" has no direct answer in the curriculum, but it relates to the same section (for more examples, see Table 1).

In order to establish inter-rater reliability, the questions were classified by two experienced science teachers and yielded $\kappa=0.66$ with one teacher (substantial agreement), and $\kappa=0.89$ (almost perfect agreement) with the second teacher. 


\begin{tabular}{|l|c|c|}
\hline \multicolumn{3}{|c|}{ Table 1: Examples of questions mapped into the curriculum } \\
\hline \multicolumn{1}{|c|}{ Curricular milestone } & $\begin{array}{c}\text { Questions directly ad- } \\
\text { dressed by the curricu- } \\
\text { lum }\end{array}$ & $\begin{array}{c}\text { Questions related to the } \\
\text { milestone that are not ad- } \\
\text { dressed by the curriculum }\end{array}$ \\
\hline $\begin{array}{l}\text { Natural resources as suppliers of human } \\
\text { needs - Natural resources as suppliers of } \\
\text { essential needs: water, air, food and pro- } \\
\text { tection + Natural resources as suppliers } \\
\text { of needs for human wellbeing, such } \\
\text { fuels and metals }\end{array}$ & $\begin{array}{l}\text { How do people use } \\
\text { nature for their own } \\
\text { needs? }\end{array}$ & $\begin{array}{l}\text { What would happen if } \\
\text { oil ran out? }\end{array}$ \\
\hline $\begin{array}{l}\text { Metal production and processing: from } \\
\text { the ore to the metal and to the final } \\
\text { product - Production: mining, quarrying } \\
\text { and refining. Processing: hammering, } \\
\text { casting and machining. }\end{array}$ & $\begin{array}{l}\text { What kinds of pro- } \\
\text { cessing methods are } \\
\text { available for } \\
\text { bronze? }\end{array}$ & $\begin{array}{l}\text { What would happen if } \\
\text { there were no resin? } \\
\text { materials? }\end{array}$ \\
\hline
\end{tabular}

\section{Online Learning Environments Development}

Student's questions were used in two interventions, using two online learning environments in each. For the first intervention, questions about "material processing" were chosen ("How do we process materials?", "How can you turn sand into glass?"). For the second intervention, questions about "materials and products" were chosen. Of the questions that addressed these two issues, we selected questions which are not addressed by the curriculum, but could be adequately answered at the elementary school level and have available online information in Hebrew.

According to Ryan and Aikenhead (1992, p. 576), if items are derived empirically from students' views rather than from science educators' positions, "researchers can feel secure in the validity of student responses". This contributes to establishing the ecological validity of our intervention. An overview of the process is described in Figure 1.

\begin{tabular}{|c|c|c|c|c|c|c|c|c|c|c|}
\hline Dec 2012 & & Dec 2012 & & Jan 2013 & & End of Jan 2013 & & Feb 2013 & & Mar 2013 \\
\hline $\begin{array}{l}\text { Collecting } \\
\text { students' } \\
\text { questions } \\
\text { addressing the } \\
\text { topic "natural } \\
\text { resources" }\end{array}$ & $\Rightarrow$ & $\begin{array}{l}\text { Mapping the } \\
\text { questions to } \\
\text { the curriculum } \\
\text { milestones }\end{array}$ & $\Rightarrow$ & $\begin{array}{l}\text { Developing } \\
\text { two online } \\
\text { learning } \\
\text { environments } \\
\text { for the topic } \\
\text { "material } \\
\text { processing" }\end{array}$ & $\Rightarrow$ & $\begin{array}{l}\text { First } \\
\text { intervention } \\
\text { The topic } \\
\text { "material } \\
\text { processing" }\end{array}$ & $\Rightarrow$ & $\begin{array}{l}\text { Developing } \\
\text { two online } \\
\text { learning } \\
\text { environments } \\
\text { on the topic } \\
\text { "materials and } \\
\text { products" }\end{array}$ & $\Rightarrow$ & $\begin{array}{c}\text { Second } \\
\text { intervention } \\
\text { The topic } \\
\text { "materials and } \\
\text { products" }\end{array}$ \\
\hline
\end{tabular}

Figure 1. Stages in the development and implementation of the "shadow curriculum" in two online formats

The homepage of the two environments in each intervention was identical. It included 14 questions, accompanied by relevant visuals (Figure 2). Each question had a link to a specific "answer page". After entering the answer page, students could go back to the homepage and choose another question. 


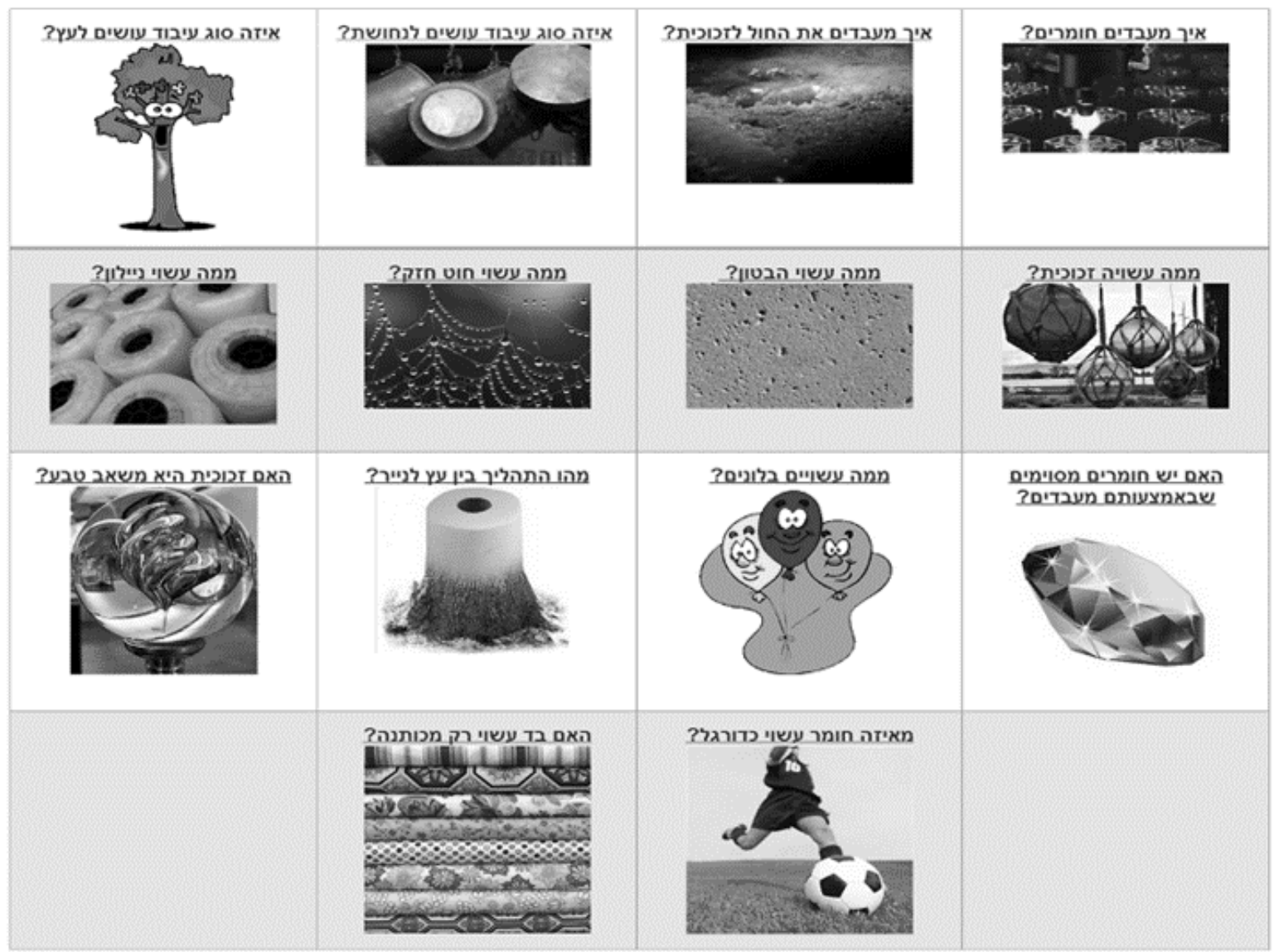

Figure 2. Homepage of the online environments on the topic "Natural Resources"

The key difference between the linear and hypermedia environment was the answer pages. The answers in the linear environment were presented in a simple linear text, so the students just had to read the answer (Figure 3a). In contrast, there was no direct answer in the hypermedia environment but links were provided that guided students to the relevant information (Figure 3b).

Another difference between the answer pages for each environment was the online feedback form. On each answer page, students were asked to indicate how interesting they considered the answer. In the hypermedia environment, they were asked to report whether they had found the answer and then whether it was interesting. 

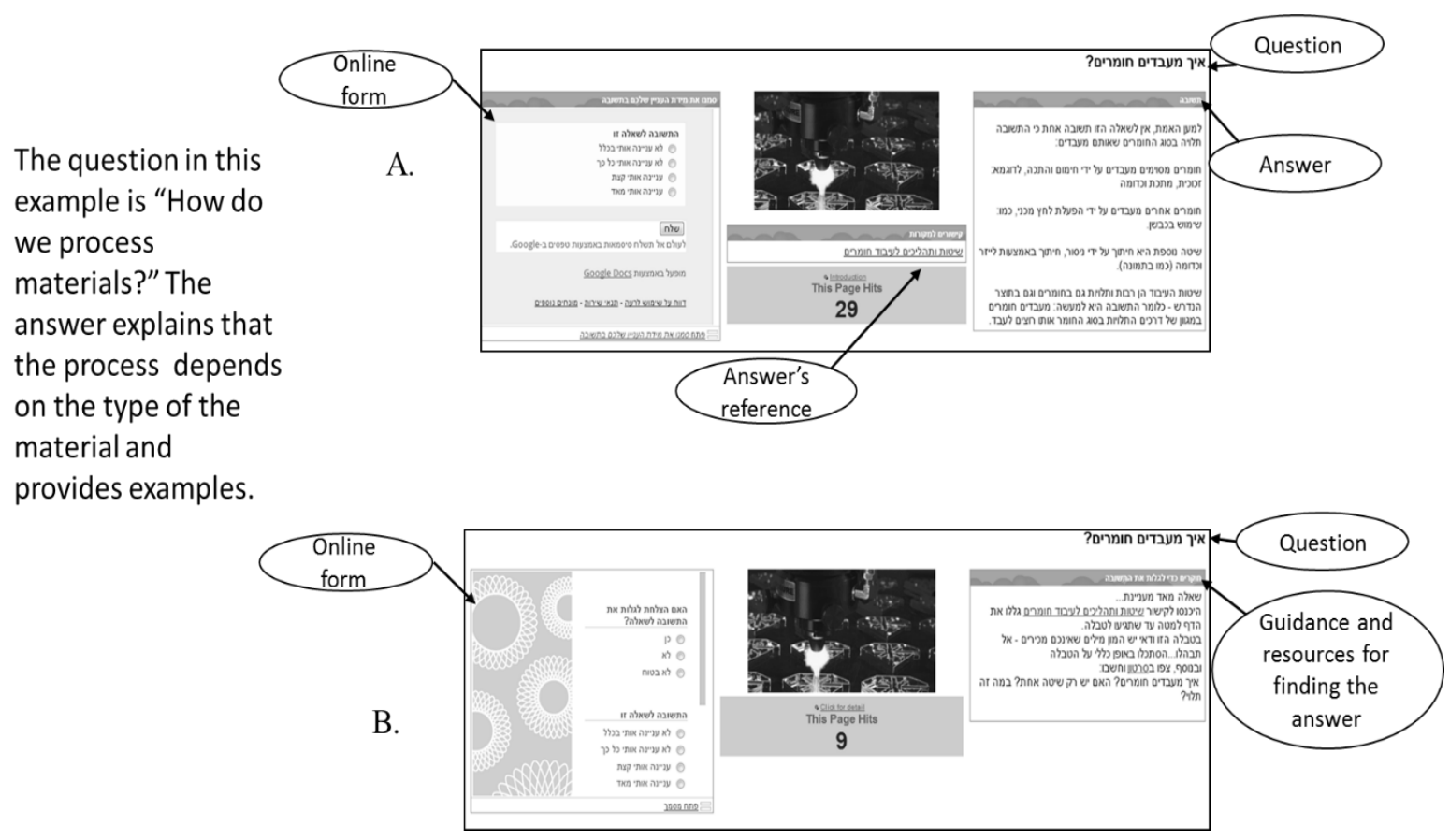

Figure 3. An example of an answer page in the A. Linear environment B. Hypermedia environment

\section{Research Tools and Data Analysis}

In order to study the effect of the online learning environments on students' level of interest and their perceived competence and relatedness, a mixed methods approach was chosen. The research tools included a short online feedback form, a questionnaire, and a class discussion. The intervention was conducted in the school computer lab. Since there were not enough computers to accommodate each student, the students worked in pairs of their own choosing. Research tools examined their responses individually (questionnaire, feedback form), as a couple (number of hits on each question) and as a group (class discussion).

\section{Questionnaire (Appendix B)}

As described in the theoretical framework, interest is a form of intrinsic motivation. According to Deci \& Ryan (1985), intrinsic motivation is based on three basic human needs: the needs for competence, relatedness, and autonomy. Since the intervention was part of the formal science class activities, we measured the first two needs - competence and relatedness directly. The need for autonomy was indirectly measured based on level of 'interest'. General interest in science was measured as well as specific interest in the topics of "space", "nutrition" and "natural resources", which are part of the 5th grade syllabus. The intervention only dealt with the last topic.

The questionnaire was made up of 20 items ranked on a 1-4 Likert scale (strongly disagreestrongly agree). Since the study was conducted with an elementary school population, the neutral option was removed in order to simplify scale for the students.

The items were divided as follows:

- Six items addressing general interest in science based on items from various questionnaires (Gonzales et al., 2008; Israeli Ministry of Education \& RAMA, 2012; Schreiner \& Sjøberg, 2004). 
- Three items addressing interest in specific learning topics: the intervention topic "natural resources" and two other topics - "space" and "nutrition", that were not included as part of the intervention. The additional topics were added in order to control for changes in interest level due to causes external to the intervention. These items were based on a questionnaire developed by Hagay and Baram-Tsabari (2011).

- Five items addressing relatedness based on a questionnaire developed by the Israeli Ministry of Education and The Psychology Service (2012).

- Two items addressing competence, one from TIMSS questionnaire (Gonzales et al., 2008) and the other from the international science test for the 5th grade (Israeli Ministry of Education \& The Psychology Service, 2012).

The questionnaire was piloted and validated on one 4 th grade class $(n=30)$. In addition, two interviews with 4th graders were conducted to see how the children interpreted the items and to verify their clarity. The pilot results led to several rephrases in some of the questionnaire items.

The reliability (internal consistency) of all 20 items, based on the pre- questionnaire results, was 0.86 using Cronbach's alpha. High reliability was found for the factors 'interest in science' $(0.81)$ and 'competence' (0.72). However, for 'relatedness' the Cronbach's alpha was unacceptable (0.31). Therefore, these were analyzed separately (see Table 2 in the Findings section). Significance was tested using independent sample T-tests as appropriate.

Although Likert items are an ordinal scale, they are often used as numeric in attitude surveys and their mean and SD are computed. Parametric statistics was used following Norman (2010) since each aggregate measure (the mean) is based on many individual responses $(n=72)$, and the results resemble normal distribution. In order to allow the reader closer inspection of our data and analysis mean, SD and actual number of response are reported.

The questionnaires were administered three times among two intervention groups and one control group (Figure 4), with temporal intervals of about a month (Figure 1): before the first intervention (pre, $n=72$ ), after the first intervention (mid, $n=69$ ) and again after the second intervention (post, $\mathrm{n}=71$ ). Intervention groups were alternated after the first intervention, so that each student experienced both types of environments. Due to privacy considerations, the questionnaires were anonymous. This prevented the pairing of individual pre-, mid- and post questionnaires. Therefore, analysis could only be done at the group level.

\section{Online feedback form}

In each answer page, students were asked to indicate how interesting the answer was in their opinion. In the hypermedia environment, they were also asked to report if they had succeeded in finding the answer. This form was used to triangulate and elaborate on the findings regarding students' interest level. Since the students worked in pairs, they were specifically asked to send a form each for every question they viewed, resulting in 349 forms.

In addition, each student was asked to write down the questions they had chosen to read on a piece of paper. This was done in order to control for cases of multiple online submissions (a student that mistakenly presses the 'submit' buttons several times).

\section{Class discussion}

In order to better understand the reasons for student preferences for each environment, about one month after the second intervention, a class discussion was held by the science teacher with the two intervention groups separately. Each discussion lasted 20 to 30 minutes. During the discussion, the students were asked which of the environments they preferred and why. The discussion was recorded, transcribed and analyzed. 


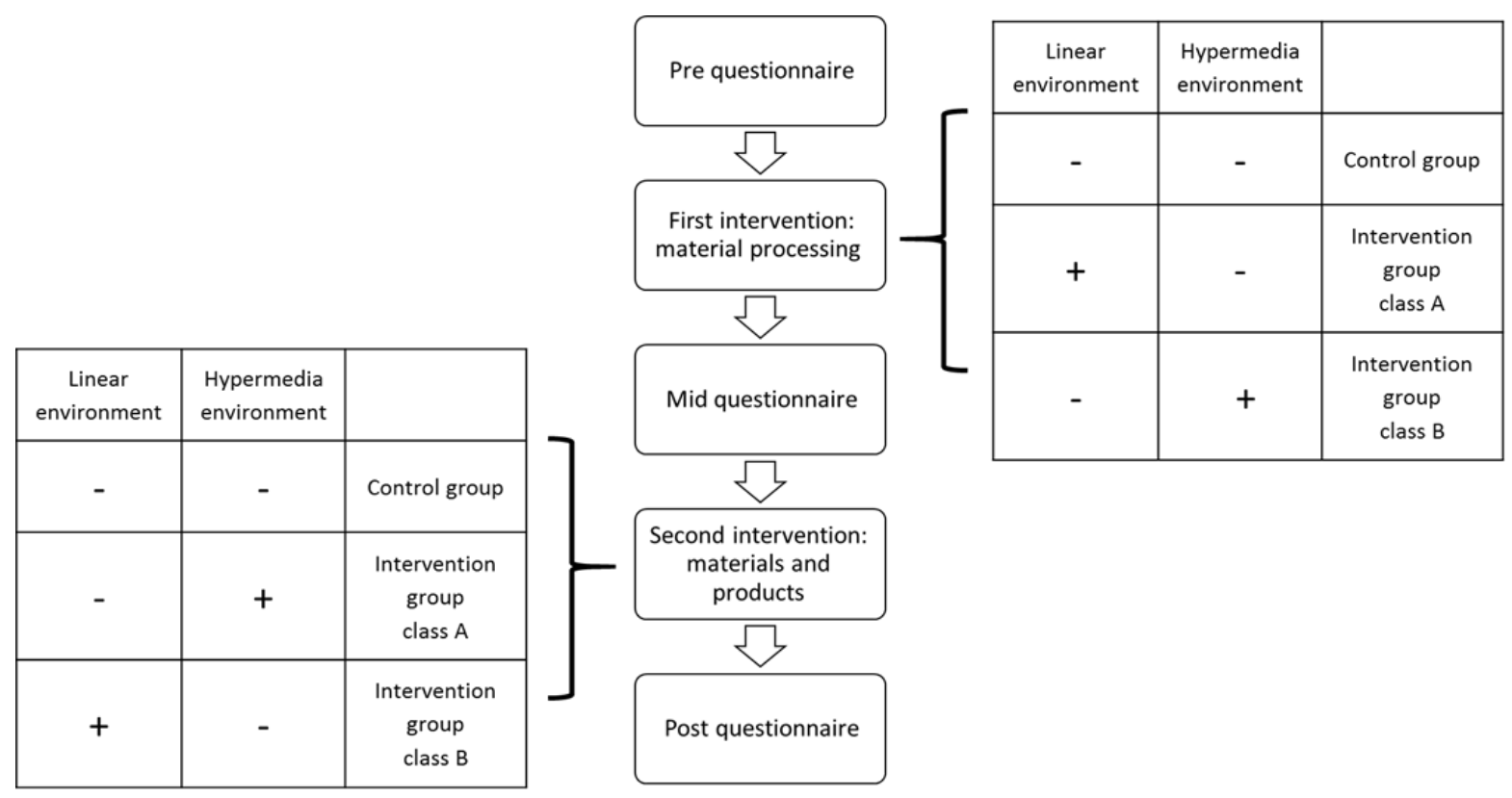

Figure 4. Research design

\section{Findings}

This study examined the effect of two types of online learning environments, which are based on students' questions, on students' interest and intrinsic motivation. We first assessed to what extent students' questions on the topic of "natural resources" are addressed by the science curriculum. Then, based on students' questions, the attitudinal outcomes of using a linear environment versus a hypermedia environment were compared.

A total of 161 questions addressing the topic of "natural resources" were anonymously collected from 585 th graders. Mapping the questions into the curriculum revealed that about $66 \%$ of questions raised by the students had no answer and were not addressed by the curriculum, despite the fact that the vast majority were in fact related to one of the milestones in the curriculum (only 10 questions failed to fit any of the curriculum milestones). For example, specific questions such as "What are soccer balls made of?", "Is cloth made only from cotton?" had no direct answer in the curriculum, but these are related to the "materials" section, in which the students are taught the general science principle: "people use materials for their needs according to the properties of these materials". The curriculum suggests using metals as an example of this principle.

Table 2 presents the number of questions addressed by the six main milestones of the curriculum in the topic of "natural resources".

For some of the curriculum milestones, no questions were mapped at all. For example, "using salt" and "the important of the Dead Sea salts and phosphates" were not included in students" questions. 


\begin{tabular}{|l|c|c|}
\hline \multicolumn{3}{|c|}{ Table 2: Distribution of questions mapped into the curriculum } \\
\hline \multicolumn{1}{|c|}{ Curricular milestone } & $\begin{array}{c}\text { Number of ques- } \\
\text { tions directly ad- } \\
\text { dressed by the } \\
\text { curriculum }\end{array}$ & $\begin{array}{c}\text { Number of ques- } \\
\text { tions related to the } \\
\text { milestone but not } \\
\text { addressed by the } \\
\text { curriculum }\end{array}$ \\
\hline Examples and definition for "natural resources" & 13 & 36 \\
\hline Metals as a type of material & 1 & 22 \\
\hline Metal production and processing & 1 & 28 \\
\hline Natural resources as suppliers of human needs & 3 & 2 \\
\hline Oil as the basic material for the plastics industry & 3 & 4 \\
\hline $\begin{array}{l}\text { The environmental cost of the use of natural re- } \\
\text { sources }\end{array}$ & 0 & \\
\hline
\end{tabular}

\section{Using the Online Learning Environments}

Using this mapping, two OLEs were developed based on students' questions from the most popular milestones, excluding the milestone regarding the definition of "natural resources" where most of the questions were in the yes/no form.

Each homepage consisted of 14 questions, which were presented in a 4 by 4 square table (Figure 2). The number of hits recorded in the first intervention was 128 (by 49 students), and in the second intervention 102 (by 42 students). The number of questions clicked by each pair ranged from 1 to 8 . We could not find any associations between the number of hits to each of the questions and the location of the questions in the homepage.

Despite the fact that most of the questions used in the environments were originally raised only by one or two students, there was a high correlation in both interventions $(\rho 1=0.81, \rho 1=0.88)$ between the number of students clicking on each question within the intervention groups. The most popular questions in the first intervention were "How can you turn sand into glass?" (16 hits) and "What are balloons made of?" (15 hits). The least popular question was "What are plastic bags made of?" (4 hits). In the second intervention, the most popular questions were "What are putty-peeps (a putty which has both solid and liquid properties) made of?" (23 hits) and "What would happen if there was no resin?" (15 hits). The least popular question was "Is it possible that in the future, an alternative for oil will be found?" (4 hits). See Appendix C for the full list of the questions and the number of hits.

\section{Differences in interest level}

Comparison of the pre and mid questionnaires, revealed a significant $(\mathrm{p}<0.05)$ increase in students' mean interest level in the intervention topic ("natural resources") after using the linear environment (LE) in the first intervention (2.19 and 2.57, respectively). In contrast, the students' mean interest level $(\mathrm{p}<0.05)$ decreased significantly after using the hypermedia environment $(\mathrm{HE})$ (2.52 and 1.95, respectively) (Figure 5). No significant difference was found in the level of interest in two other topics, "space" and "nutrition", that were not included as part of the intervention. In the control group, which was made of 5th graders that did not participate in the intervention, there was a non-significant decrease in students' interest level ( 2 and 1.66, respectively). 


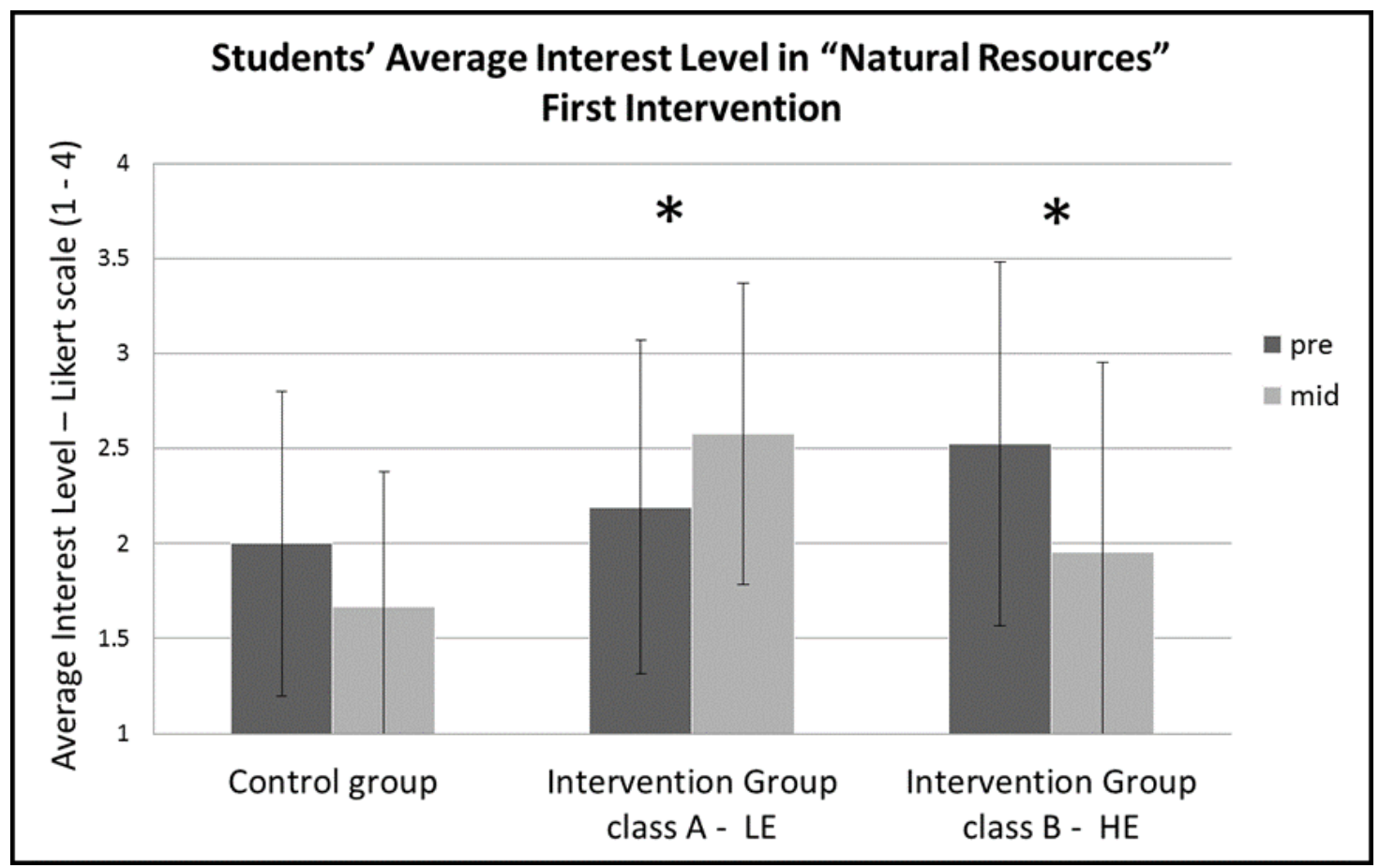

* indicates significance at $\mathrm{p}<0.05$.

Figure 5. Students' mean interest level in the intervention topic "natural resources"

After the second intervention students' interest level decreased in all groups but not significantly (control group 1.66 and 1.41; HE 2.57 and 2.4; LE 1.95 and 1.85).

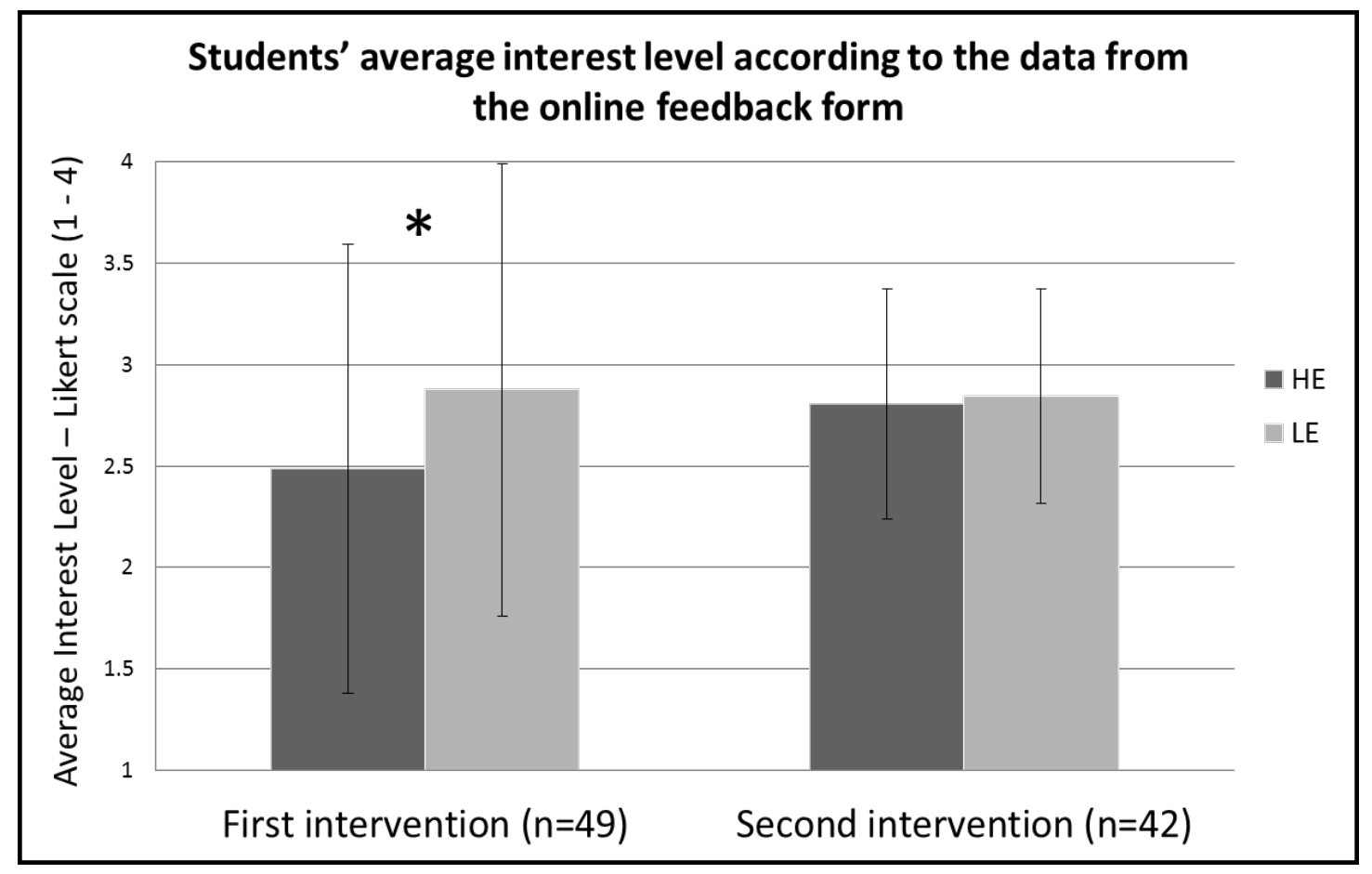

* indicates significance at the $\mathrm{p}<0.05$

Figure 6. Students' mean interest level according to the data from the online feedback form 
This result was supported by data from the online feedback form, which was integrated into every answer page in both environments. The students were asked to mark how interesting the answer was for them. In the first intervention, the students exposed to the LE reported a significantly $(p<0.05)$ higher interest level than the students who experienced the HE. In the second intervention there was no difference between the interest levels in the two environments (see Figure 6).

\section{Students' Perceived Competence and Relatedness}

No significant difference was found with regard to perceived competence after the first intervention (control group 2.2 and 2.52; LE 2.8 and 2.73; HE 2.57 and 2.66, respectively). However, after the second intervention, the mean competence level of the students who experienced the hypermedia environment increased significantly, compared to the competence level in the mid questionnaire (2.7 and 3.03, respectively, $\mathrm{p}<0.05)$ (Figure 7).

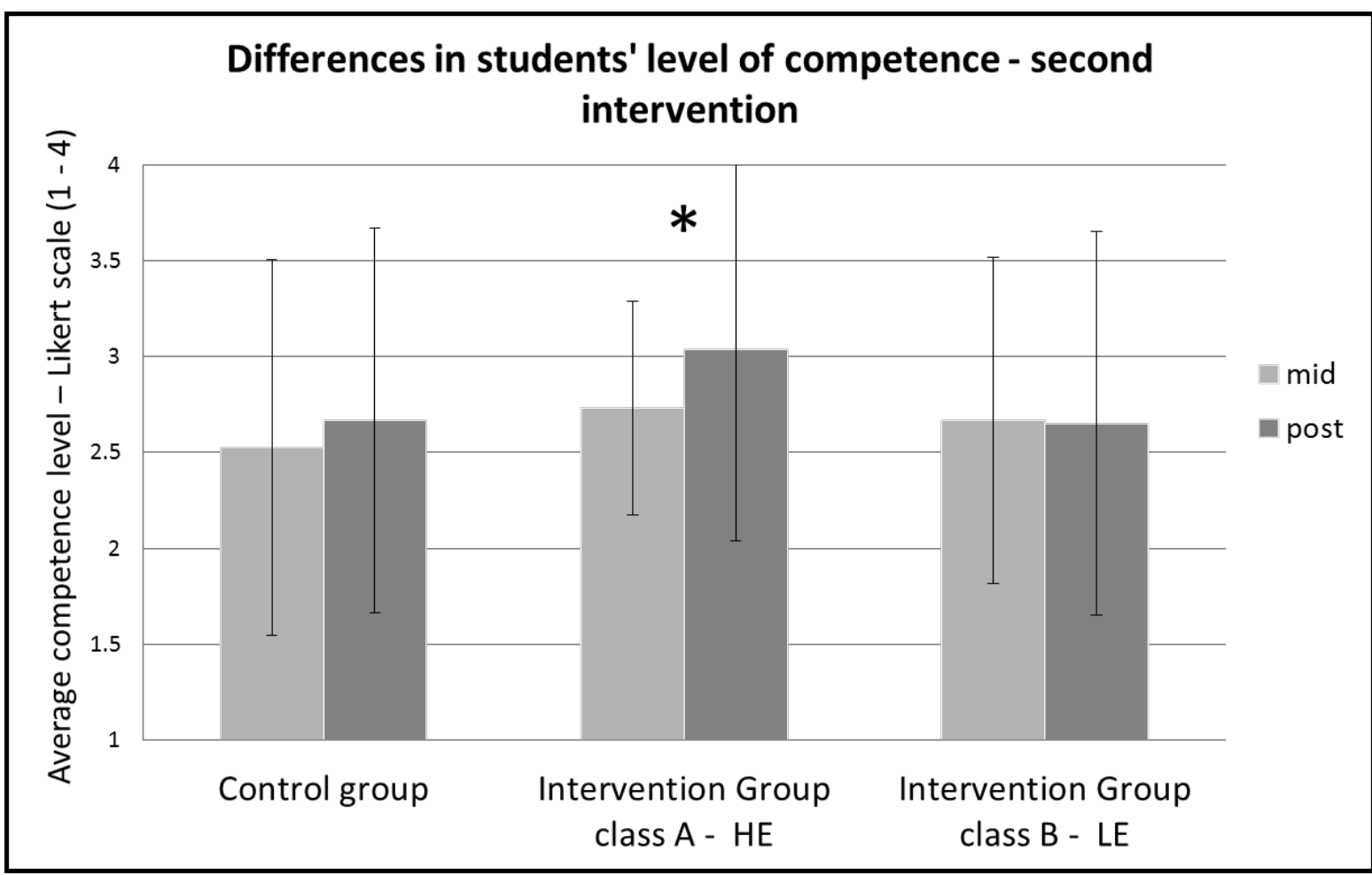

* indicates significant at $\mathrm{p}<0.05$

Figure 7. Students' level of perceived competence before and after the second intervention

Significant differences in students' relatedness levels were found after the first intervention (premid questionnaires).

As seen in Table 3 (bold indicates significance at $\mathrm{p}<0.05$ level), after using the linear environment, there was an increase in all five items measuring a feeling of relatedness (actual results are detailed in Appendix D). However, this increase was only significant $(\mathrm{p}<0.05)$ for the item "I feel that the questions I raise in science class affects its content". On the other hand, after using the hypermedia environment this index decreased significantly $(\mathrm{p}<0.05)$. Another significant decrease was found in the item concerning the students' influence on science lessons after using the hypermedia environment $(\mathrm{p}<0.01)$. No significant differences were found for the control group. 


\begin{tabular}{|l|c|c|c|c|c|c|c|c|c|c|c|}
\hline \multicolumn{7}{|c|}{ Table 3: Differences in students' level of competence and relatedness } \\
Bolded - significance (p<0.05) \\
\hline
\end{tabular}

\section{Students' Preferences}

The class discussions conducted with each of the intervention classes one month after the second intervention, encouraged students to contribute their own perspective on the OLE and the strategy of using their own questions as a starting point for learning.

When asked which they preferred - the "hypermedia environment" or the "linear environment" most students orally reported that they prefer the linear one. The time needed for getting the answer was one of the explanations, as one student plainly said: "when I ask a question it means that I don't want to find the answer by myself. If I did, I wouldn't have asked it at all! - I'm happy to have the answer and this is how I learn" (female in class B). Another reason was the adjustment and suitability of the answers to students' level: "I prefer the simple answer [the linear environment], because I understand it better, it was clear. When I looked for the answer [the hypermedia environment] sometimes it was hard to understand" (female in class A).

However, not all the students preferred the easier and shorter way. Three students, who had an excellent achievement level in science, said that the hypermedia environment was their preferred environment. They claimed that looking for the answer by using the links was more challenging and interesting and enabled them to discover new information. As one of the students said, "If you already have the answer, it doesn't help you. You just read. The main idea is to find the answer by myself" (f $\backslash$ class B). Another explanation for this preference was the visualization of the answer. "I prefer the links [the hypermedia environment]; it was more visual than just reading the answer [the linear environment]" ( $\mathrm{m} \backslash$ class A). A summary of all reasons mentioned in the class discussions appears in Figure 8. The numbers in parentheses represents the number of students who mentioned the explanation.

To recap the findings, each intervention drew a different picture. In the first intervention, the interest level increased after experiencing learning with the linear environment and decreased after experiencing the hypermedia environment. After the second intervention, students' interest level decreased in all the groups but not significantly. However, the competence level increased only after using the hypermedia environment in the second intervention. 


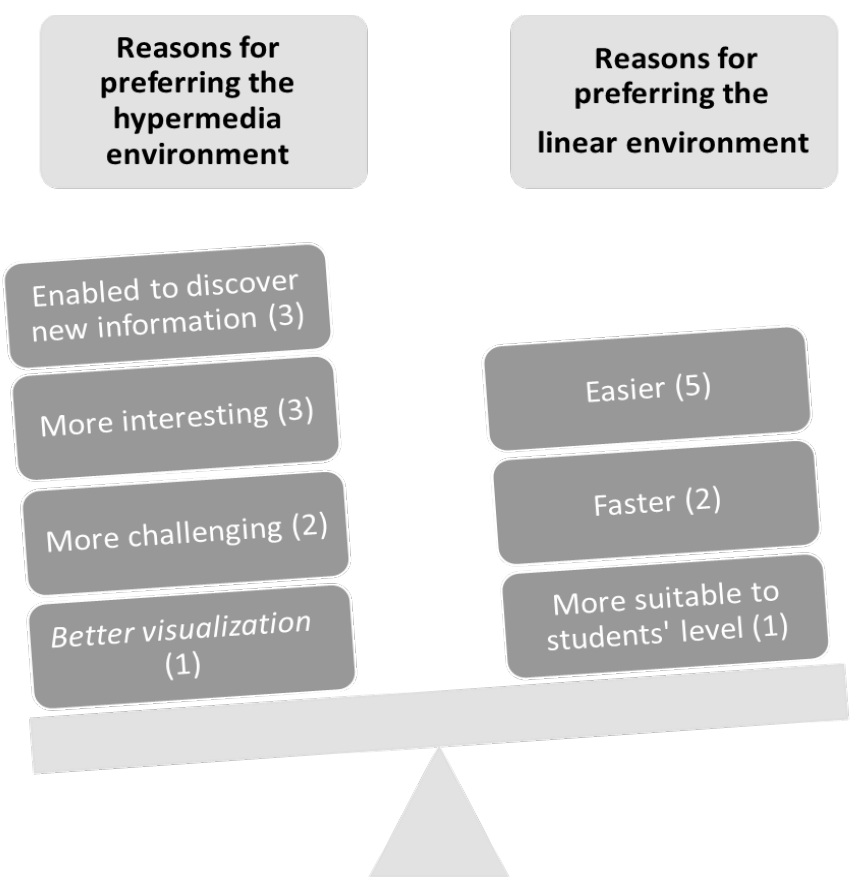

Figure 8: Reasons for preferences of each of the environments

\section{Research Limitations}

The main limitation of this study was that the intervention was conducted only twice, yielding different results each time. One possible cause behind this inconsistency is that each intervention included fewer than $10 \%$ of the 161 collected questions. Therefore, the results might have been different if other questions had been included or if another topic had been used. Another potential cause might be that students found the repeated activity and measurement less exciting the second time it was administered.

Secondly, due to privacy considerations, the questionnaires were anonymous. This prevented the pairing of individual pre, middle and post questionnaires. Therefore, analysis could only be done at the group level.

Data collection was done using a 1-4 Likert scale. In hindsight, a 1-5 scale might have been a better choice, allowing a neutral point.

In addition, one of the researchers was also the teacher, who collected the data, designed the OLE, and led the interventions. This could lead to a certain bias in the results, such as reactive effects of experimental arrangements (Campbell \& Stanley, 1963) that may be caused by students' desire to satisfy their teacher.

Another limitation is that, despite the random assignment of classes to the control and intervention groups, this was still a quasi-experimental rather than experimental design. Analysis of the pre-questionnaire revealed significant differences in students' interest and relatedness level between the control group and the interventions groups. Therefore, the ability to compare these groups was limited.

Lastly there is an uncontrolled variability in the educational level of the links provided in the hypermedia environment, e.g., the length of each link, the text level, its appearance, etc. Such a variance may influence interest and motivation levels. 
Future studies could benefit from a text analysis of the hyperlinks and an analysis of students' study skills on regular texts to test their ability to find answers.

\section{Conclusions}

The questions that students raise in class can reflect their interests. These interests are often marginalized or ignored by the science curriculum. Hagay and Baram-Tsabari (2011) found such a gap between high school biology students and the biology curriculum serving them in Israel. In this study, we found that such a gap also exists between students' interests, as reflected by the questions they would like to ask, and the elementary school science curriculum.

Naturally, the curriculum cannot contain the answers to each and every student's question. However, we found that most students' questions could be addressed in connection with different curriculum milestones, even though there was no direct answer in the curriculum. A correlation was found in the popularity of the questions between the two intervention groups, i.e., different cohorts of students seem to be interested in similar questions. These findings may indicate the value of using the "shadow curriculum" strategy for incorporating students' interests into the formal science curriculum, or maybe changing the curriculum.

The first intervention successfully integrated students' questions with the science curriculum, resulting in an increase in students' interest levels. However, these findings were not observed in the second intervention. One possible explanation could be the change in the intervention topic, which may have been less interesting to the students in general or the fatigue of repeating a similar activity, known as "multiple treatment interference" (Campbell \& Stanley, 1963).

Differences in students' interest level using OLE has been studied previously, for example by Barak et al. (2011). Thus, in this study we developed two OLEs which differed in their pedagogical concepts. The analysis revealed a significant increase in the interest level after using the linear environment, while after using the hypermedia environment, students' interest level decreased. Regarding the intrinsic motivation component, in contrast to the LE (linear environment), the HE (hypertext environment) was found to be effective for competence, but ineffective for relatedness.

Scheiter and Gerjets (2007, p. 301) wrote that "It is often argued that hypermedia has many advantages for learning. Unfortunately, reviews on hypermedia learning have failed to provide much support in favor of these claims", and the findings of this study support this observation. Since hypermedia environments enable learners to have control over the arrangement of content (Shapiro \& Niederhauser 2004) and helps them construct the answer themselves, we assumed that it would increase interest and motivation in learning, but our findings paint a more complex picture.

In this study, students expressed more interest in the plain text of the linear environment that provided an answer written by the teacher. Students attributed this preference to the shorter time needed to find the answer and the compatibility of the answers to their level of understanding.

However, some of the high achieving students said that the hypermedia environment enabled them to discover new information, and challenged them more. Hence the ambiguity regarding the effectiveness of hypermedia learning environments may be a result of differences between learners. According to Eshet and Hammer (2006), the potential effectiveness for the learner from learning with hypermedia depends on the learners' digital and cognitive skills, due to the fact that "even when controlling for Internet access and experiences, people differ in their online abilities and activities" (Hargittai, 2010, p. 92). Thus, the recommendation stemming from our findings is the importance of adjusting the environment to the students' level, both in the content and in the pedagogical method, and giving them the opportunity to choose which way is best for them. 
In this work, we explored a practical and viable way for introducing a student driven curriculum into the elementary science class, while focusing on its effect on intrinsic motivation. This study may also contribute to the body of literature addressing the role of OLEs in enhancing extrinsic motivation. Chen and Jang (2010) suggest online instructors to "create an open, interactive, and learner-centered atmosphere for students to freely express their feelings, thoughts, and concerns" (p. 750). This study may point that this "learner-centered atmosphere" may be influenced not only by applying learner-centered pedagogy, but also by using learner-centered content. A synergy between content, which builds on students' existing interests and constructivist pedagogy, could make the OLE more motivating to students.

\section{Acknowledgments}

This research was supported by the I-CORE Program of the Planning and Budgeting Committee and The Israel Science Foundation (1716/12).

The authors wish to express their gratitude to Dr. Galit Hagay and Dr. Ran Peleg for their useful contributions to the research design.

\section{Appendix A}

Translated questionnaire based on the "probing questionnaire" in Hagay and Baram-Tsabari (2011, p. 630). I am a boy / girl grade:

$\mathrm{Hi}$,

Today, we will begin learning the topic "Natural Resources".

Please write down the questions related to the topic of "Natural Resources" that you would like to know the answer to. The questions can relate to everyday life, and do not necessarily need to be something you learn in school. I would appreciate it if you could explain why the questions interest you (personal reason, something I read, something I learned, rumors, curiosity, faith, something I saw on TV, etc.)

You may use the following types of questions: Do/Does...? How...? Why...? What is the connection between...? When...? What would happen if...? How... influences on ...?

\begin{tabular}{|l|l|}
\hline Why am I interested in this question? & My question \\
\hline & \\
\hline & \\
\hline & \\
\hline
\end{tabular}

(More space was left in the original questionnaire) 


\section{Appendix B}

Translated questionnaire

$\mathrm{Hi}$,

In this questionnaire, you will find statements about interest in science learning.

Please indicate how much you agree with each of these statements.

I am a boy / girl grade:

\begin{tabular}{|l|c|c|c|c|}
\hline & $\begin{array}{c}\text { Strongly } \\
\text { disagree }\end{array}$ & Disagree & Agree & $\begin{array}{c}\text { Strongly } \\
\text { agree }\end{array}$ \\
\hline Science is boring & 1 & 2 & 3 & 4 \\
\hline $\begin{array}{l}\text { I like school science better than most other sub- } \\
\text { jects }\end{array}$ & 1 & 2 & 3 & 4 \\
\hline $\begin{array}{l}\text { In my spare time I enjoy watching Science/ Na- } \\
\text { ture/ Environment programs (on TV or computer) }\end{array}$ & 1 & 2 & 3 & 4 \\
\hline $\begin{array}{l}\text { In my spare time I enjoy reading newspapers, } \\
\text { books, online articles, etc. related Science/ Nature/ } \\
\text { Environment }\end{array}$ & 1 & 2 & 3 & 4 \\
\hline I would like to become a scientist & 1 & 2 & 3 & 4 \\
\hline $\begin{array}{l}\text { The things that I learn in science at school will be } \\
\text { helpful in my daily life }\end{array}$ & 1 & 2 & 3 & 4 \\
\hline $\begin{array}{l}\text { I am interested in topics related to food, nutrition } \\
\text { and digestion }\end{array}$ & 1 & 2 & 3 & 4 \\
\hline I am interested in topics related to space & 1 & 2 & 3 & 4 \\
\hline $\begin{array}{l}\text { I am interested in topics related to natural re- } \\
\text { sources }\end{array}$ & 1 & 2 & 3 & 4 \\
\hline I usually do well in science & 1 & 2 & 3 & 4 \\
\hline $\begin{array}{l}\text { Science is harder for me than for many of my } \\
\text { classmates }\end{array}$ & 1 & 2 & 3 & 4 \\
\hline $\begin{array}{l}\text { Students can influence the content taught in a sci- } \\
\text { ence lesson }\end{array}$ & 1 & 2 & 3 & 4 \\
\hline $\begin{array}{l}\text { I feel that the questions I raise in science class af- } \\
\text { fect its content }\end{array}$ & 1 & 2 & 3 & 4 \\
\hline My classmates think I have stupid ideas & 1 & 2 & 3 & 4 \\
\hline I feel that science teachers respect me & & 2 & 3 & 4 \\
\hline $\begin{array}{l}\text { I feel there is no point asking questions in science } \\
\text { class because no one will answer them anyway }\end{array}$ & 1 & 3 & 4 \\
\hline Is there anyting else you & & & & \\
\hline
\end{tabular}

Is there anything else you would like to add? 


\section{Appendix C}

\begin{tabular}{|c|c|c|c|}
\hline \multicolumn{2}{|l|}{ Number of hits - First intervention } & \multicolumn{2}{|l|}{ Number of hits - second intervention } \\
\hline How can you turn sand into glass? & 16 & $\begin{array}{l}\text { What are putty-peeps (a putty which has both solid and liquid } \\
\text { properties) made of?" }\end{array}$ & 23 \\
\hline What are balloons made of? & 15 & What would happen if there was no resin? & 15 \\
\hline Are there specific materials that are used in processing? & 12 & How do bees make honey? & 10 \\
\hline What is the process of making paper from a tree? & 11 & How are cars made? & 9 \\
\hline Is glass a natural resource? & 11 & How is a whiteboard made? & 9 \\
\hline Is cloth made only from cotton? & 11 & Where does candle wax come from? & 8 \\
\hline What strong wires are made of? & 10 & How is a camera made? & 6 \\
\hline What are soccer balls made of? & 9 & What would happen if the oil ran out? & 4 \\
\hline What glass is made of? & 7 & When and how was the wood table created? & 3 \\
\hline What concrete blocks are made of? & 7 & What is petroleum? & 3 \\
\hline How do we process materials? & 6 & Why do we need oil? & 3 \\
\hline What kinds of processing methods are available for bronze? & 5 & How are light bulbs made? & 3 \\
\hline What kinds of processing methods are available for wood? & 4 & How are clocks made? & 3 \\
\hline What are plastic bags made of? & 4 & Is it possible that in the future, an alternative for oil will be found? & 2 \\
\hline
\end{tabular}

\section{Appendix D}

\begin{tabular}{|c|c|c|c|c|c|c|c|}
\hline \multicolumn{8}{|c|}{ Differences in students' level of relatedness - actual results } \\
\hline & \multirow{2}{*}{$\frac{0}{\overparen{D}}$} & \multicolumn{2}{|c|}{ Control group } & \multicolumn{2}{|c|}{$\begin{array}{l}\text { Intervention group - class A } \\
\text { (Linear environment) }\end{array}$} & \multicolumn{2}{|c|}{$\begin{array}{r}\text { Intervention group - class B } \\
\text { (Hypermedia environment) }\end{array}$} \\
\hline & & pre $(n=25)$ & $\operatorname{mid}(n=21)$ & pre $(n=26)$ & $\operatorname{mid}(n=26)$ & pre $(n=21)$ & $\operatorname{mid}(n=21)$ \\
\hline \multirow{4}{*}{$\begin{array}{l}\text { Students can influence the content taught in a science } \\
\text { lesson }\end{array}$} & 1 & 9 & 7 & 1 & 0 & 0 & 3 \\
\hline & 2 & 3 & 0 & 5 & 5 & 3 & 3 \\
\hline & 3 & 5 & 7 & 15 & 12 & 11 & 11 \\
\hline & \begin{tabular}{|l|}
4 \\
\end{tabular} & 6 & 7 & 5 & 9 & 7 & 4 \\
\hline \multirow{4}{*}{$\begin{array}{l}\text { I feel that the questions | raise in science class affect } \\
\text { its content }\end{array}$} & 1 & 9 & 5 & 4 & 2 & 2 & 6 \\
\hline & 2 & 4 & 6 & 8 & 9 & 6 & 10 \\
\hline & 3 & 7 & 8 & 13 & 11 & 7 & 4 \\
\hline & \begin{tabular}{|l|}
4 \\
\end{tabular} & 2 & 2 & 1 & 4 & 6 & 1 \\
\hline \multirow[t]{4}{*}{ My classmates think I have stupid ideas } & 1 & 15 & 10 & 18 & 16 & 14 & 11 \\
\hline & 2 & 6 & 5 & 3 & 8 & 6 & 6 \\
\hline & 3 & 2 & 4 & 3 & 1 & 1 & 1 \\
\hline & 4 & 2 & 2 & 2 & 1 & 0 & 3 \\
\hline \multirow[t]{4}{*}{ I feel that science teachers respect me } & 1 & 5 & 5 & 1 & 0 & 1 & 3 \\
\hline & 2 & 4 & 2 & 0 & 1 & 3 & 2 \\
\hline & 3 & 7 & 4 & 15 & 14 & 7 & 11 \\
\hline & 4 & 9 & 10 & 10 & 11 & 10 & 5 \\
\hline \multirow{4}{*}{$\begin{array}{l}\text { I feel there is no point asking questions in science } \\
\text { class because no one will answer them anyway }\end{array}$} & \begin{tabular}{|l|}
1 \\
\end{tabular} & 11 & 13 & 9 & 18 & 13 & 8 \\
\hline & 2 & 8 & 6 & 10 & 5 & 6 & 6 \\
\hline & 3 & 2 & 0 & 6 & 0 & 2 & 3 \\
\hline & \begin{tabular}{|l|}
4 \\
\end{tabular} & 4 & 2 & 1 & 3 & 0 & 4 \\
\hline
\end{tabular}




\section{References}

Ainley, M., \& Ainley, J. (2011). A cultural perspective on the structure of student interest in science. International Journal of Science Education, 33(1), 51-71.

Ainley, M., Hidi, S., \& Berndorff, D. (2002). Interest, learning, and the psychological processes that mediate their relationship. Journal of Educational Psychology, 94(3), 545-561.

Barak, M., Ashkar, T., \& Dori, Y. J. (2011). Learning science via animated movies: Its effect on students' thinking and motivation. Computers \& Education, 56(3), 839-846.

Baram-Tsabari, A., \& Yarden, A. (2005). Characterizing children's spontaneous interests in science and technology. International Journal of Science Education, 27(7), 803-826.

Baram-Tsabari, A., \& Yarden, A. (2007). Why are we interested in interest? The American Biology Teacher, 69(9), 532-540.

Campbell, D. T., \& Stanley, J. C. (1963). Experimental and quasi-experimental designs for research. Chicago, IL: Rand McNally.

Cannady, M. A., Greenwald, E., \& Harris, K. N. (2014). Problematizing the STEM pipeline metaphor: Is the STEM pipeline metaphor serving our students and the STEM workforce? Science Education, 98(3), 443-460.

Chen, K. C., \& Jang, S. J. (2010). Motivation in online learning: Testing a model of self-determination theory. Computers in Human Behavior, 26(4), 741-752.

Chin, C., \& Osborne, J. (2008). Students' questions: A potential resource for teaching and learning science. Studies in Science Education, 44(1), 1-39.

Christidou, V. (2011). Interest, attitudes and images related to science: Combining students' voices with the voice of school science, teachers, and popular science. International Journal of Environmental and Science Education, 6(2), 141-159.

Cohen, A., Kalimi, S., \& Nachmias, R. (2013). The use of digital repositories for enhancing teacher pedagogical performance. Interdisciplinary Journal of E-Learning \& Learning Objects, 9, 201-218. Retrieved from http://www.ijello.org/Volume9/IJELLOv9p201-218Cohen0861.pdf

Cook-Sather, A. (2002). Authorizing student perspectives: Toward trust, dialogue, and change in education. Educational Researcher, 31(4), 3-14.

Cuccio-Schirripa, S., \& Steiner, H. E. (2000). Enhancement and analysis of science question level for middle school students. Journal of Research in Science Teaching, 37(2), 210-224.

Davie, R., \& Galloway, D. (1996). The voice of the child in education. In R. Davie, \& D. Galloway (Eds.), Listening to children in education (pp. 2-14). London: David Fulton.

Deci, E. L., \& Ryan, R. M. (1985). Intrinsic motivation and self-determination in human behavior. New York: Plenum.

Dewey, J. (1916). Democracy and education. NY, The Free Press.

Dillon, A., \& Gabbard, R. (1998). Hypermedia as an educational technology: A review of the quantitative research literature on learner comprehension, control, and style. Review of Educational Research, $68(3), 322-349$.

Dori, Y. J., Barak, M., \& Adir, N. (2003). A web-based chemistry course as a means to foster freshmen learning. Journal of Chemical Education, 80(9), 1084-1092.

Eshet, Y., \& Hammer, R. (2006). Principles of design and analysis of computer-based learning environments. Raanana, Israel: Open University (In Hebrew). 
Falc, E. O. (2013). An assessment of college students' attitudes towards using an online etextbook. Interdisciplinary Journal of E-Learning \& Learning Objects, 9, 1-12. Retrieved from http://www.ijello.org/Volume9/IJELLOv9p001-012Falc831.pdf

Geri, N., Gafni, R., \& Winer, A. (2014). The U-Curve of e-learning: Course website and online video use in blended and distance learning. Interdisciplinary Journal of E-Learning \& Learning Objects, 10, 1 16. Retrieved from http://www.ijello.org/Volume10/IJELLOv10p001-016Geri0473.pdf

Gonzales, P., Williams, T., Jocelyn, L., Roey, S., Kastberg, D., \& Brenwald, S. (2008). Highlights from TIMSS: 2007 Mathematics and Science Achievement of U.S. Fourth- and Eighth-Grade Students in an International Context (NCES 2009-001). Washington, DC: US Department of Education, Institute of Education Sciences, National Center for Educational Statistics. Retrieved December 10, 2012, from http://timss.bc.edu/TIMSS2007/PDF/T07_SudentQ_G4.pdf

Hagay, G., \& Baram-Tsabari, A. (2011). A shadow curriculum: Incorporating students' interests into the formal biology curriculum, Research in Science Education, 41(5), 1-24.

Hagay, G., \& Baram-Tsabari, A. (2012). Including students' voices as engagement with curriculum: Perspectives from a secondary biology course. Canadian Journal for Science, Mathematics, and Technology Education, 12(2), 1-18.

Hans, M., Kali, Y., \& Yair, Y. (2011). Developing spatial abilities by integrating information communication technologies (ICT) with simple physical means. In D. Chen \& G. Kurtz (Eds.), ICT, learning and teaching (pp. 101-124). Or Yehuda: The Center for Academic Studies. (In Hebrew).

Hargittai, E. (2010). Digital na (t) ives? Variation in internet skills and uses among members of the "net generation”. Sociological Inquiry, 80(1), 92-113.

Hennessy, E. (1999). Children as service evaluators. Child and Adolescent Mental Health, 4(4), 153-161.

Hsu, C., Hwang, G., Chuang, C., \& Chang, C. (2012). Effects on learners' performance of using selected and open network resources in a problem-based learning activity. British Journal of Educational Technology, 43(4), 606-623.

Hu, H. W., \& Chiou, G. F. (2012). The types, frequency and quality of elementary pupil's questions in an online environment. Turkish Online Journal of Educational Technology, 11(4), 325-335.

Israeli Ministry of Education. (2013). Syllabus of science and technology studies in elementary school (in Hebrew). Jerusalem: State of Israel Ministry of Education Curriculum Center.

Israeli Ministry of Education \& The Psychology Service. (2012). Best possible educational climate questionnaire (in Hebrew). Retrieved December 10, 2012, from http://cms.education.gov.il/EducationCMS/Units/Shefi/avoda/tfasim/SheelonAhm.htm

Israeli Ministry of Education \& RAMA - The National Authority for Measurement and Evaluation in Education (2012). Growth and effectiveness measures of school: Science and technology test for the 5th grade (in Hebrew). Retrieved December 10, 2012, from http://meyda.education.gov.il/files/Rama/25mad-012-5A-SOF-net.pdf

Jenkins, E. W., \& Nelson, N. W. (2005). Important but not for me: Students' attitudes towards secondary school science in England. Research in Science \& Technological Education, 23(1), 41-57.

Jidesjö, A., Oscarsson, M., Karlsson, K-G. \& Strömdahl, H. (2009). Science for all or science for some: What Swedish students want to learn about in secondary science and technology and their opinions on science lessons. Nordina, 5(2), 213-229.

Jonassen, D.H. (1986). Hypertext principles for text and courseware design. Educational Psychologist, 21(4), 269-292.

Kaplan, A., Katz, E., \& Flume, F. (2012). Motivation theory in educational practice: Knowledge claims, challenges, and future directions. In: K. R. Harris, S. Graham, \& T. Urdan (Eds.), APA Educational psychology handbook, Vol. 2: Individual differences and cultural contextual factors (pp. 165-194). American Psychological Association. 
Kirschner, P. A., \& van Merriënboer, J. J. (2013). Do learners really know best? Urban legends in education. Educational Psychologist, 48(3), 169-183.

Koul, R., Lerdpornkulrat, T., \& Chantara, S. (2011). Relationship between career aspirations and measures of motivation toward biology and physics, and the influence of gender. Journal of Science Education and Technology, 20(6), 761-770.

Krapp, A., \& Prenzel, M. (2011). Research on interest in science: Theories, methods, and findings. International Journal of Science Education, 33(1), 27-50.

Mayer, R. E., \& Moreno, R. (2003). Nine ways to reduce cognitive load in multimedia learning. Educational Psychologist, 38(1), 43-52.

Murray, I., \& Reiss, M. (2005). The student review of the science curriculum. School Science Review, 87(318), 83-93.

Norman, G. (2010). Likert scales, levels of measurement and the "laws" of statistics. Advances in Health Sciences Education, 15(5), 625-632.

OECD. (2009). Top of the class: High performers in science in PISA 2006. PISA, OECD Publishing. Retrieved May 18, 2014 from

http://www1.oecd.org/education/school/programmeforinternationalstudentassessmentpisa/topoftheclas s-highperformersinscienceinpisa2006.htm

Potvin, P., \& Hasni, A. (2014). Interest, motivation and attitude towards science and technology at K-12 levels: A systematic review of 12 years of educational research. Studies in Science Education, 50(1), 85-129.

Renninger, K. A., \& Hidi, S. (2011). Revisiting the conceptualization, measurement, and generation of interest. Educational Psychologist, 46(3), 168-184.

Rosen, Y. (2009). The effects of an animation-based on-line learning environment on transfer of knowledge and on motivation for science and technology learning. Journal of Educational Computing Research, $40(4), 451-467$.

Rouet, J. F., \& Levonen, J. J. (1996). Studying and learning with hypermedia: Empirical studies and their implication. In J. F. Rouet, J. J. Levonen, A. Dillon, \& R. J. Spiro (Eds.), Hypermedia and cognition. (pp. 9-23). Mahwah, NJ: Lawrence Erlbaum.

Ryan, A. G., \& Aikenhead, G. S. (1992). Students' preconceptions about the epistemology of science. Science Education, 76(6), 559-580.

Scardamalia, M., \& Bereiter, C. (1992). Text-based and knowledge-based questioning by children. Cognition and Instruction, 9(3), 285-307.

Scheiter, K., \& Gerjets, P. (2007). Learner control in hypermedia environments. Educational Psychology Review, 19(3), 285-307.

Schreiner, C., \& Sjøberg, S. (2004). Sowing the seeds of ROSE. Background, rationale, questionnaire development and data collection for ROSE (The Relevance of Science Education) - A comparative study of students' views of science and science education. Oslo: Dept. of Teacher Education and School Development, University of Oslo. Retrieved December 10, 2012, from http://www.uv.uio.no/ils/english/research/projects/rose/actadidactica.pdf

Shapiro, A., \& Niederhauser, D. (2004). Learning from hypertext: Research issues and findings. In D. H. Jonassen (Ed.), Handbook of research on educational communications and technology (2nd ed, pp. 605-620). Mahwah, NJ: Erlbaum.

Swarat, S., Ortony, A., \& Revelle, W. (2012). Activity matters: Understanding student interest in school science. Journal of Research in Science Teaching, 49(4), 515-537.

Toshalis, E., \& Nakkula, M. J. (2012). Motivation, engagement, and student voice. Education Digest, 78(1), 29-35. 


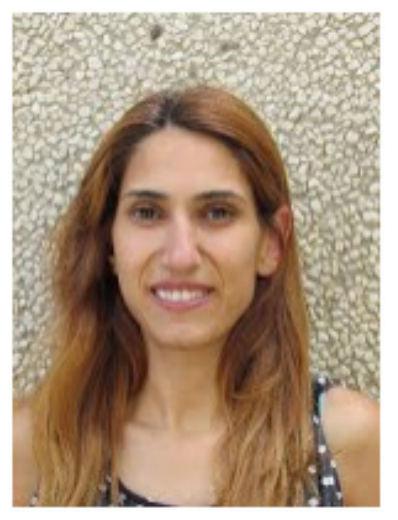

\section{Biographies}

Hani Swirski completed her BSc and MEd at the Technion - Israel Institute of Technology at the Department of Education in Science and Technology in Physics education. From 2005 to 2013, she worked at an elementary school in the northern part of Israel, teaching science. During the last two years, she trained teachers to use ICT tools in teaching while maximizing their pedagogical value. Now she is a $\mathrm{PhD}$ student in the Department of Education in Science and Technology under the supervision of Prof. Ayelet Baram-Tsabari. Her research focuses on integrating student voice into the science curriculum using online learning environment, which is based on students' questions.

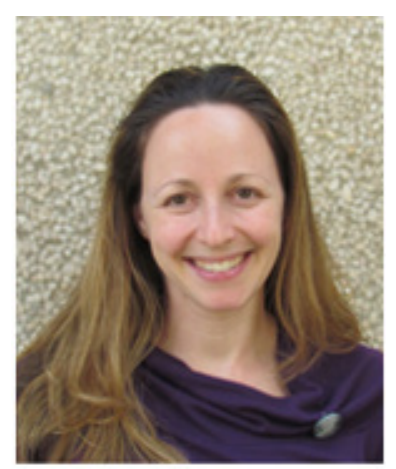

Ayelet Baram-Tsabari is an Assistant Professor at the Technion Israel Institute of Technology, and head of the Biology Education and Science Communication research groups at the Department of Education in Science and Technology. She is a Landau Fellow for Leaders in Science and Technology Program, an Allon Fellow for Outstanding Young Researchers, and a member of the Learning in a Networked Society (LINKS) Israeli center of Research Excellence (ICORE).

Her main research interests are in bridging science education and science communication scholarship, including identifying peoples' interests in science and building on these authentic interests to teach and communicate science in more meaningful and personally relevant ways. 